\title{
FAKTOR DETERMINAN DALAM PENDIDIKAN: GURU SEBAGAI PENDIDIK PROFESIONAL
}

\section{DETERMINANT FACTORS IN EDUCATION: TEACHERS AS PROFESSIONAL EDUCATOR}

\author{
Nurqadriani1), Baso Syafaruddin ${ }^{2}$ ) \\ 1)STAI YAPIS Takalar, ${ }^{2) I n s t i t u t ~ A g a m a ~ I s l a m ~ A s ' a d i y a h ~ S e n g k a n g ~}$ \\ nurqadriani@staiyapistakalar.ac.id ${ }^{1}$,, basosyafaruddin89@gmail.com²)
}

\begin{abstract}
Abstrak
Penelitian ini bertujuan untuk mendeskripsikan faktor-faktor determinan dalam pendidikan dan mendeskripsikan guru sebagai pendidik profesional. Penelitian ini adalah penelitian pustaka (library research). Penelitian ini menggunakan analisis data content analysis. Hasil penelitian pertama menunjukkan bahwa terdapat lima faktor yang determinan dalam pendidikan yaitu faktor pendidik, peserta didik, tujuan pendidikan, alat pendidikan dan lingkungan pendidikan. Hal tersebut merupakan kunci utama untuk menjaga dan meningkatkan eksistensi lembaga pendidikan. Suatu lembaga pendidikan yang tidak didukung dengan kelima faktor determinan tersebut akan menyebabkan ketimpangan terhadap capaian pendidikan karena kelima faktor tersebut saling memengaruhi. Kedua, profesionalitas guru ditandai dengan pendidikan formal yang dilakukan di lembaga pendidikan sesuai dengan bidang keahlian serta mampu melakukan tugasnya yaitu mengajar, mendidik, membimbing, mengarahkan, melatih dan menilai peserta didik. Kedudukan guru sebagai pendidik telah diatur dalam regulasi yang memberikan kesempatan kepada setiap guru dalam mengembangkan kreatifitasnya pada saat menjalankan tugas. Oleh karena itu, setiap guru dituntut untuk terus mengembangkan kompetensi diri sesuai dengan tuntutan perkembangan peradaban dan bekal dalam menjalankan tugas secara profesional. Hal tersebut merupakan keniscayaan yang harus disadari oleh setiap pendidik.
\end{abstract}

Kata Kunci: determinan, pendidikan, guru, profesional

\begin{abstract}
This study aims to describe the determinants of education and to describe teachers as professional educators. This research is a research library. This study uses content analysis data analysis. The results of the first study indicate that there are five determinant factors in education, namely factors of educators, students, educational objectives, educational tools, and the educational environment. This is the primary key to maintaining and improving the existence of educational institutions. An educational institution that is not supported by these five determinant factors will cause inequality in educational attainment because these five factors influence each other. Second, teacher professionalism is characterized by formal education carried out in educational institutions in accordance with their areas of expertise and being able to carry out their duties, namely teaching, educating, guiding, directing, training, and assessing students. The position of teachers as educators has been regulated in regulations that provide opportunities for every teacher to develop their creativity while carrying out their duties. Therefore, every teacher must continue developing self-competence in accordance with the demands of civilization development and provision to carry out duties professionally. This is a necessity that every educator must realize.
\end{abstract}

Keywords: determinant, education, teacher, professional 
How to Cite: Nurqadriani \& Syafaruddin, B. (2021). Faktor determinan dalam pendidikan: guru sebagai pendidik profesional. Al asma: Journal of Islamic Education, 3(1), 64-72.

\section{PENDAHULUAN}

Pendidikan merupakan hal yang sangat vital dalam mengembangkan bangsa menjadi bangsa yang makmur dan sejahtera. Faktor determinan dalam pendidikan harus secara sinergi saling melengkapi dan mendukung agar tercapai tujuan pendidikan. Pendidik, peserta didik, tujuan, alat dan lingkungan pendidikan sangat berperan penting.

Peningkatan dan pengembangan pendidikan yang berkualitas harus dilakukan melalui pengadaan dan peningkatan kualitas faktor determinan dalam pendidikan. Oleh karena itu setiap lembaga pendidikan harus mampu untuk mengatur berbagai kebutuhan lembaga khususnya terhadap faktor determinan pendidikan yang sesuai dengan regulasi dan perkembangan peradaban.

Kualitas pendidikan ditentukan oleh kualitas sumber daya manusia yang berada dalam lingkup pendidikan. Salah satunya adalah guru. Guru merupakan salah satu unsur yang esensial dalam pengembangan pendidikan. Bahkan segala uapaya seharusnya dilakukan agar peningkatan guru, baik dari segi kualitas maupun kuantitas terlaksana dengan baik.

Guru sebagai pendidik prosfesional merupakan figur yang sangat penting dalam pendidikan, khususnya pendidikan formal. Karena Seorang guru yang menjadi pelaku utama dalam mempersiapkan peserta didik, melakukan persiapan pembelajaran, proses pembelajaran dan evaluasi pembelajaran kepada peserta didiknya. Semua hal tersebut dilakukan sebagai perwujudan atas profesionalisme guru.

Berberapa tulisan yang telah mengangkat tentang faktor determinan dalam pendidikan Saat (2015) berpendapat bahwa faktor-faktor determinan dalam pendidikan studi tentang makna dan kedudukannya dalam pendidikan. Penelitian ini membahas tengtang kedududukan dan eksistensi faktor determinan dalam mewujudkan tujuan pendidikan.

Djuanda (2019) meningkatkan kompetensi guru sebagai pendidik profesional dalam mengembangkan pembelajaran. Penelitian ini membahas tentang upaya dalam mengembangkan potensi guru pada bidang pembelajaran. Serlinda, Sasongko, dan Zakaria (2019) komitmen guru dalam meningkatkan kompetensi profesional sebagai pendidik. Penelitian ini menggambarkan upaya seorang pendidik dalam meningkatkan kompetensi yang dimiliki dalam mendukung profesionalitas yang dimiliki.

Gambaran hasil penelitian di atas menunjukkan bahwa belum ada yang membahas secara signifikan tentang faktor determinan dalam dunia pendidikan dan guru sebagai pendidik profesional. Oleh karena itu, tulisan ini dibuat untuk mengetahui hal-hal mendasar dan penting dalam dunia pendidikan yaitu faktor-faktor yang determinan dalam dunia pendidikan dan guru sebagai pendidik yang profesional.

\section{METODE PENELITIAN}

Tulisan ini menggunakan pendekatan penelitian kualitatif dengan jenis penelitian library research yang membahas tentang faktor yang determinan dalam dunia pendidikan dan guru sebagai pendidik yang profesional. Teknik pengumpulan data yang digunakan dalam penelitian ini adalah dokumentasi yang diperoleh melalui referensi dari buku dan 
jurnal yang relevan dengan topik pebahasan pada tulisan ini. Analisis yang digunakan untuk menganalisis data pada tulisan ini adalah content analysis.

\section{HASIL DAN PEMBAHASAN}

\section{Faktor Determinan Pendidikan}

Pendidikan adalah bagian yang urgen yang berperan penting dalam menentukan kelangsungan kehidupan peradaban di dunia. Terlaksananya sebuah pendidikan ditentukan oleh lima faktor yang determinan. Yaitu faktor pendidik, peserta didik, tujuan pendidikan, alat pendidikan, dan lingkungan pendidikan. Kelima komponen tersebut saling terkait satu sama lain sehingga demi terciptanya pendidikan yang berkualitas maka ditentukan oleh kualitas komponen-komponen tersebut.

\section{Pendidik}

Pendidik adalah seseorang yang memiliki tugas untuk pendidik atau memberikan pendidikan. Pendidikan yang dimaksudkan adalah mendidik, membina, membimbing, memelihara, menumbuhkan dan mengarahkan agar menjadi lebih baik. Dalam Kamus Besar Bahasa Indonesia pendidik berarti “Orang yang mendidik" (Poerwadarminta, 1991). Orang yang mendidik diantaranya guru, dosen, tutor, instruktur, widyaswara, pamong belajar, konselor, dan lain-lain sesuai dengan profesi dan pekerjaannya.

Pendidik dalam Islam berarti orang yang memiliki tanggung jawab pada perkembangan yang dididik yaitu peserta didik dengan usaha untuk mengembangkan potensi yang dimiliki oleh peserta didik tersebut, baik pada ranah kognitif, afektif, dan psikomotorik (Tafsir, 2002). Pendidik menurut Abdul Mujib adalah "Bapak rohani (spiritual father) bagi peserta didik, yang memberikan santapan jiwa dengan ilmu, pembinaan akhlak mulia, dan meluruskan perilaku yang buruk" (Mujib, 2008). Berdasarkan beberapa pendapat tersebut, maka dapat dikatakan bahwa pendidik merupakan orang yang diberikan tanggung jawab terhadap jiwa dan rohani peserta didik sehingga mampu mengembangkan potensinya pada ranah kognitif, afektif, dan psikomotorik.

Pendidik dikelompokkan berdasarkan statusnya yaitu pendidik karena kodratnya dan pendidik karena profesinya. Pendidik berdasarkan kodratnya yang dimaksudkan yaitu orang tua dan pendidik berdasarkan profesinya adalah guru (Saat, 2015). Keduanya merupakan pendidik yang memiliki peran masing-masing yang sama pentingnya dalam memberikan pendidikan. Orang tua sebagai pendidik dimulai pada saat kelahiran anaknya. Ketika anaknya lahir, maka otomatis orang tua memiliki tanggung jawab mendidik anaknya. Pendidikan dari orang tua ini adalah kodrat yang tidak bisa digantikan perannya oleh siapapun. Orang tua sebagai pembimbing dalam lingkungan keluarga disebabkan karena secara alami anak-anak pada masa awal kehidupannya berada ditengah-tengah ayah dan ibunya (Ramayulis \& Nizar, 2010). Oleh karena itu, orang tua memiliki peranan penting dalam memajukan pendidikan karena orang tua adalah madrasah pertama bagi perkembangan ilmu pengetahuan bagi anak-anaknya.

Selain orang tua, guru merupakan pendidik yang memiliki peran tidak kalah pentingnya bagi peserta didik. Bila orang tua adalah pendidik di lingkungan keluarga, maka guru adalah pendidik pada pendidikan formal. Berdasarkan Undang-Undang RI No. 20 Tahun 2003 tentang Sistem Pendidikan Nasional pasal 1 ayat 6 "Yang disebut sebagai 
pendidik adalah tenaga kependidikan" (Undang-Undang RI No. 20 Tahun 2003 tentang Sistem Pendidikan Nasional) dan Undang-Undang tentang Guru dan Dosen pada pasal 1 ayat 1 disebutkan "Guru adalah pendidik profesional" (Undang-Undang No. 14 Tahun 2005 tentang Guru dan Dosen.)

Guru merupakan seseorang yang harus serba tahu dan serba bisa dalam memberikan ilmu pengetahuan kepada peserta didiknya yaitu dengan membantu peserta didik mengembangkan potensi yang dimilikinya. Guru sebagai tenaga pengajar berperan penting dan aktif dalam proses pendewasaan peserta didik (Ramli, 2015). Seorang guru harus memiliki sikap dan menjadi teladan yang baik bagi peserta didiknya. Selain dari ilmu pengetahuan yang dimiliki oleh guru yaitu termasuk kompetensi profesional, seorang guru juga harus memenuhi kompetensi pedagogik dan sosial untuk menjadi tenaga pengajar yang profesional. Guru adalah seseorang yang memiliki memiliki tanggung jawab yang sangat besar terhadap dirinya dan peserta didiknya.

\section{Peserta Didik}

Peserta didik adalah seseorang yang masih belum dewasa dan memiliki potensi dari dalam dirinya dan menjadi fitrahnya yang harus dikembangkan (Suharto, 2011). Berdasarkan fitrahnya, peserta didik seperti barang mentah yang baru akan diolah oleh guru. Peserta didik merupakan individu yang memiliki ciri khas pada setiap tahap pertumbuhan serta perkembangan potensinya yang dapat dipengaruhi oleh lingkungannya (Ramayulis \& Nizar, 2010).

Sebagai individu yang memiliki potensi dalam dirinya, seorang peserta didik harus mampu mengembangkan potensi tersebut dengan mengalami proses pendidikan. Proses perkembangan pada peserta didik membutuhkan pemenuhan kebutuhan untuk tumbuh dan berkembang sampai mencapai kematangan fisik dan psikisnya. Kebutuhan peserta didik yang harus dipenuhi khususnya oleh pendidik adalah kebutuhan jasmani, kebutuhan sosial, dan kebutuhan intelektual (Ramli, 2015).

Kebutuhan jasmani peserta didik ditandai dari tuntutan jasmaniah peserta didik, yaitu mencakup kesehatan jasmani atau olah raga. Selain itu kebutuhan jasmaniah yang lainnya yaitu makanan, minuman, tidur, pakaian dan sebagainya.

Kebutuhan sosial peserta didik ditandai dengan tuntutan sosialnya, yaitu kebutuhan bersosial dengan sesama peserta didik, dengan guru dan orang lain. Di lingkungan sekolah akan terjadi interaksi sosial untuk para peserta didik belajar dan bergaul dengan para peserta didik serta beradaptasi dengan lingkungan sekolah yang di dalamnya terdapat berbagai suku, agama, ras, jenis kelamin dan status sosial. Dengan interaksi tersebut diharapkan mampu memberikan pengalaman belajar yang baik bagi peserta didik.

Kebutuhan intelektual peserta didik ditandai dengan kebutuhan memperoleh ilmu pengetahuan. Setiap siswa memiliki karakteristik dan tingkat keinan untuk memperoleh ilmu pengetahuan, mulai dari keinginan yang keras, sampai tidak memiliki keinginan. Atau ada pula yang berkeinginan terhadap salah satu mata pelajaran. Keinginan peserta didik ini merupakan keinginan yang tidak dapat diubah oleh guru akan tetapi dapat dioptimalkan dengan memberikan kenyamanan pada peserta didik dalam belajar.

Oleh karena itu, peserta didik menjadi posisi yang sangat penting dalam keberhasilan pendidikan. Setiap peserta didik memiliki potensi dari dalam dirinya yang harus dikembangkan melalui proses pendidikan. Pengembangan potensi peserta didik ini 
dapat tercapai dengan pemenuhan kebutuhan-kebutuhan peserta didik yaitu kebutuhan jasmaniah, sosial dan intelektual. Kebutuhan tersebut dipenuhi dengan terjalinnya hubungan yang baik antara semua komponen pendidikan.

\section{Tujuan Pendidikan}

Tujuan adalah seperti sebuah ujung jalan yang akan didatangi. Setiap hal harus memiliki tujuan agar tidak kesasar. Sama halnya dengan pendidikan yang memiliki tujuan. Tujuan pendidikan seperti anak tangga yang memiliki puncak yang diupayakan agar dapat diraih. Untuk meraihnya, maka perlu dilalui setiap anak tangga tersebut mulai dari yang paling bawah sampai pada puncaknya. Bukan hal yang mudah untuk mencapai tujuan pendidikan, dibutuhkan usaha yang maksimal oleh seluruh komponen pendidikan.

Tujuan memiliki fungsi untuk mengakhiri usaha, mengarahkan usaha, merupakan titik pangkal untuk mencapai tujuan-tujuan lain, dan memberikan nilai pada usaha apakah berhasil atau tidak (Marimba, 1964). Tujuan pendidikan mengarahkan pendidikan kearah yang diinginkan sehingga dapat dikategorikan keberhasilan proses jalannya pendidikan.

Fungsi ditetapkannya tujuan pendidikan adalah untuk mengarahkan proses pendidikan sehingga memiliki arah yang jelas dan untuk mengetahui ukuran hasil pendidikan. Tujuan pendidikan semestinya dapat diukur, proses pendidikan ditetapkan berdasarkan tujuan-tujuan pendidikan yang terarah, dan pada akhir proses pendidikan dapat dilakukan penilai berdasarkan berhasil tidaknya tujuan yang hendak dicapai tersebut.

Tujuan pendidikan yang seperti anak tangga, seperti yang dipaparkan sebelumnya, adalah mulai dari anak tangga paling bawah, hingga anak tangga paling atas. Anak tangga paling bawah dalam pembelajaran adalah dimulai dari merumuskan tujuan pembelajaran dan indikator, lalu menetapkan kompetensi inti, standar kompetensi, tujuan instruksional, tujuan pendidikan nasional, lalu kemudian tujuan hidup nasional. Tujuan hidup nasional tidak dapat tercapai apabila tujuan pembelajaran, indikator, kompetensi inti, standar kompetensi, tujuan instruksional dan tujuan pendidikan nasional tidak tercapai. Apabila tujuan dibawahnya tidak tercapai maka sulit untuk tercapainya tujuan hidup nasional.

Tujuan pendidikan pendidikan tersebut terdiri dari tujuan umum dan khusus yaitu berupa perubahan-perubahan yang diinginkan seperti cabang-cabang tujuan atau tujuan umum kemudian cabang tujuan tersebut menurun menjadi ranting-ranting tujuan atau tujuan khusus. Tujuan tersebut akan mengalami perbahan sesuai dengan proses kehidupan manusia dan perubahan dari zaman ke zaman (Zuhairini, 1992). Hal inilah yang mendasari perubahan-perubahan kurikulum pendidikan. Meskipun demikian tujuan umum dan khusus ini akan mengarahkan tercapainya pendidikan karena perubahan tersebut dapat diukur dan dievaluasi untuk mengetahui ketercapaiannya.

\section{Alat Pendidikan}

Alat pendidikan adalah segala hal yang digunakan untuk mencapai tujuan pendidikan. Alat pendidikan merupakan semua perlengkapan yang digunakan dalam untuk mencapai tujuan pendidikan (Saat, 2015). Selain menjadi perlengkapan pendidikan, alat pendidikan juga menjadi segala hal yang dapat membantu dan mempermudah berjalannya proses pendidikan. Perlengkapan pendidikan haruslah sesuatu yang benarbenar dapat membantu berjalannya proses pendidikan dan meminimalisir hambatanhambatan yang akan memperlambat tercapainya proses pendidikan. 
Menurut Saat (2015) alat pendidikan dapat dibagi berdasarkan fungsinya, yaitu:

a) Alat sebagai perlengkapan

b) Alat sebagai pembantu mempermudah usaha mencapai tujuan

c) Alat sebagai tujuan.

Sedangkan dari segi kegunaannya, alat pendidikan dapat dibagi atas:

a) Alat langsung, yaitu alat pendidikan yang sifatnya langsung menganjurkan dan sesuai dengan pendidikan, misalnya peraturan, anjuran, dan kewajiban yang harus dipenuhi sesuai dengan segala akibatnya.

b) Alat tidak langsung, yaitu alat yang sifatnya mencegah hal-hal yang tidak sesuai dengan usaha, misalnya, larangan, peringatan yang segala akibatnya.

Alat pendidikan hampir sama dengan media pendidikan. Bedanya adalah terletak pada fisiknya. Media fisiknya adalah benda berwujud dan konkret, sedangkan alat adalah segala sesuatu baik benda berwujud mapun abstrak. Media digunakan untuk menjadi perantara oleh pengirim pesan kepada penerima pesan (Sadiman, Rahardjo, Haryono, \& Harjito, 2008). Alat pendidikan termasuk di dalamnya media, aktivitas pembelajatan, metode pembelajaran, anjuran pendidik, perintah, larangan, reward maupun hukuman dan lain-lain yang dilakukan untuk mewujudkan tercapainya tujuan pendidikan.

Maka dari itu, alat pendidikan cakupannya lebih luas dari pada media pendidikan. Apabila alat tersebut digunakan oleh pendidik untuk menyampaikan pesan atau mentransfer ilmu pengetahuannya kepada peserta didik maka itu disebut media. Namun apabila alat yang digunakan dalam proses pembelajaran, maka itu dinamakan alat pendidikan.

\section{Lingkungan Pendidikan}

Lingkungan pendidikan merupakan komponen pendidikan yang memiliki peran cukup penting dalam mencapai tujuan pendidikan. Lingkungan pendidikan yaitu lingkungan sosial dan non sosial. Lingkungan sosial pendidikan adalah lingkungan yang di dalamnya terdapat manusia yang berada di sekitar peserta didik, baik pendidik, orang tua, masyarakat dan sesama peserta didik yang memiliki pengaruh terhadap peserta didik itu sendiri dari pada lingkungan tempatnya bergaul. Sedangkan lingkungan non sosial yaitulingkungan sekitarnya berupa situasi dan keadaan, misalnya keadaan sekolah, suasana ruangan belajar, peralatan belajar, cuaca dan iklim tempat belajar dan semacamnya yang dapat mempengaruhi peserta didik (Saat, 2015).

Lingkungan pendidikan dalam arti luas mencakup iklim geografis, tempat tinggal, adat istiadat, pengetahuan, pendidikan dan alam (Zakiah, 2006). Lingkungan merupakan segala sesuatu yang nampak di dalam kehidupan yang dapat berubah dan berkembang seiring berjalannya waktu. Lingkungan ini sangat mempengaruhi perkembangan seseorang baik dari segi positif maupun negatif. Lingkungan pendidikan lebih sering terjadi di sekolah. Selain di sekolah, proses pendidikan dapat pula terjadi di rumah dan di masyarakat. Lingkungan tersebut adalah tripusat pendidikan. Lingkungan tersebut dapat berpengaruh baik atau buruk terhadap pendidikan tergantung bagaimana lingkungan ini ditata dengan sebaik mungkin.

7. Guru Sebagai Pendidik Profesional

a. Pengertian Profesi Guru

Profesi adalah pekerjaan yang dalam pelaksanaan tugasnya diperlukan keahlian khusus, menggunakan teknik-teknik ilmiah serta berdedikasi tinggi (Hasanan, 2012). 
Keahlian tersebut diperoleh berdasarkan jenjang pendidikan dari lembanga pendidikan yang dikhususkan untuk mencetak profesi tersebut. Profesi merupakan suatu pekerjaan atau jabatan yang menuntuk keahlian tertentu (Hasan, 2011). Keahlian yang diperoleh diperuntukkan kepada pekerjaan atau jabatan yang mensyaratkan keterampilan dan ilmu pengetahuan khusus dari pendidikan yang tidak singkat dan secara intensif.

Profesi guru adalah profesi atau pekerjaan ahli yang dimiliki oleh seseorang yang telah melakukan proses pendidikan keguruan yang memadai (Hasanan, 2012). Peran guru sebagai pendidik yang ahli selain mengajar adalah mendidik, membimbing, melatih, merealisasikan ilmu pengetahuan yang dimilikinya kepada peserta didik demi kemaslahatan dan fungsinya sebagai guru. Guru sebagai pengajar juga melakukan kegiatan pembimbingan, misalnya bimbingan belajar dan bimbingan keterampilan terhadap peserta didiknya. Sehingga dapat dipahami bahwa di dalam proses pendidikan, seorang guru dapat melakukan kegiatan mengajar, mendidik, membimbing dan menilai. Kegiatan guru tersebut tidak dapat dipisah-pisahkan antara satu sama lain (Suriyati, 2019). Berdasarkan beberapa pendapat tersebut dapat disimpulkan bahwa guru adalah pekerjaan yang profesional yang bertugas untuk mengajar, mendidik, membimbing, mengarahkan, melatih dan menilai peserta didik di jenjang pendidikan formal

b. Karakteristik Guru Profesional

Seorang guru profesional terlihat dari cara guru melaksanakan tugasnya sebagai tenaga profesi baik dari segi materi, maupun segi metode. Keahlian seorang guru akan ditunjukkan melalui tanggungjawab yang dilakukannya dengan profesional dalam melaksanakan seluruh aspek yang mencakup aspek sosial, intelektual, moral dan spiritual. Menurut Usman (2002) berpendapat bahwa terdapat perbandingan antara sikap profesional dan amatir, yaitu:

Tabel 1. Perbandingan guru professional dan guru amatis menurut Uzer Usman

\begin{tabular}{ll}
\hline Guru Profesional & Guru Amatir \\
\hline $\begin{array}{l}\text { Memandang tugas sebagai bagian dari } \\
\text { ibadah. }\end{array}$ & Memandang tugas semata-mata bekerja. \\
\hline $\begin{array}{l}\text { Memandang guru adalah profesi mulia dan } \\
\text { terhormat. }\end{array}$ & Memandang profesi guru biasa saja. \\
\hline Menganggap bahwa beker itu amanah. & $\begin{array}{l}\text { Memandang kerja itu hanya mencari } \\
\text { nafkah }\end{array}$ \\
\hline $\begin{array}{l}\text { Memandang profesi guru sebagai } \\
\text { panggilan jiwa. }\end{array}$ & $\begin{array}{l}\text { Memandang profesi guru sebagai } \\
\text { keterpaksaan }\end{array}$ \\
\hline $\begin{array}{l}\text { Menganggap kerja itu nikmat dan } \\
\text { menyenangkan. }\end{array}$ & $\begin{array}{l}\text { Memandang kerja itu beban dan } \\
\text { membosankan }\end{array}$ \\
\hline $\begin{array}{l}\text { Menganggap kerja itu sebagai bentuk } \\
\text { pengabdian }\end{array}$ & $\begin{array}{l}\text { Memandang kerja itu murni mencari } \\
\text { penghasilan }\end{array}$ \\
\hline $\begin{array}{l}\text { Memiliki rasa/ ruhul jihad dalam } \\
\text { mengajarnya }\end{array}$ & $\begin{array}{l}\text { Mengajar sekadar menggugurkan } \\
\text { kewajiban }\end{array}$ \\
\hline Mempelajari setiap aspek dari tugasnya & Tidak mempelajari tugasnya. \\
\hline $\begin{array}{l}\text { Secara cermat menemukan apa yang } \\
\text { diperlukan dan diinginkan }\end{array}$ & $\begin{array}{l}\text { Merasa sudah cukup dengan apa yang } \\
\text { diperlukan dan diinginkan }\end{array}$ \\
\hline $\begin{array}{l}\text { Memandang, berbicara dan berbusana } \\
\text { secara sopan dan elegan }\end{array}$ & Berpenampilan dan berbicara semaunya. \\
\hline
\end{tabular}


Sejalan dengan hal tersebut, Pusrwanto (2009) mengemukakan bahwa: "Sifat guru yang baik adalah adil, percaya dan suka terhadap murid-muridnya, sabar dan rela berkorban, memiliki kewibawaan terhadap anak-anak, penggembira, bersikap baik terhadap guru-guru lainnya, bersikap baik terhadap masyarakat, mengausai pelajaran, suka terhadap mata pelajaran, dan berpengetahuan luas".

Berdasarkan beberapa pendapat di atas, maka dapat disimpulkan bahwa guru harus memiliki jenjang pendidikan formal yang ahli di bidangnya, menguasai teknik dalam proses pembelajaran, serta menguasai landasan keprofesionalan.

\section{SIMPULAN}

Pendidikan adalah bagian yang urgen yang berperan penting dalam menentukan kelangsungan kehidupan peradaban di dunia. Terlaksananya sebuah pendidikan ditentukan oleh lima faktor yang determinan. Yaitu faktor pendidik, peserta didik, tujuan pendidikan, alat pendidikan, dan lingkungan pendidikan. Kelima komponen tersebut saling terkait satu sama lain sehingga demi terciptanya pendidikan yang berkualitas maka ditentukan oleh kualitas komponen-komponen tersebut. Guru adalah pekerjaan yang profesional yang bertugas untuk mengajar, mendidik, membiinbing, mengarahkan, melatih dan menilai peserta didik di jenjang pendidikan formal. Guru harus memiliki jenjang pendidikan formal yang ahli di bidangnya, menguasai teknik dalam proses pembelajaran, serta menguasai landasan keprofesionalan.

\section{DAFTAR PUSTAKA}

Djuanda, I. (2019). Meningkatkan kompetensi guru sebagai pendidik profesional dalam mengembangkan pembelajaran. 2019, I(2), 353-372.

Hasan, A. M. (2011). Pengembangan profesi guru. Malang: Alfabeta.

Hasanan, A. (2012). Pengembangan profesi guru. Bandung: CV Pustaka Setia.

Marimba, A. D. (1964). Pengantar filsafat pendidikan Islam. Bandung: PT AL Ma'rif.

Mujib, A. (2008). Ilmu pendidikan Islam. Jakarta: Kencana Prenada Media.

Poerwadarminta, W. J. . (1991). Kamus umum bahasa Indonesia. Jakarta: Balai Pustaka.

Pusrwanto, N. (2009). Ilmu pendidikan teoritis dan praktis. Bandung: PT Remaja Rosdakarya.

Ramayulis, \& Nizar, S. (2010). Filsafat pendidikan Islam: telaah sistem pendidikan dan pemikiran para tokohnya. Jakarta: Kalam Mulia.

Ramli, M. (2015). Hakikat pendidik dan peserta didik. Tarbiyah Islamiyah, 1(1), 1-6.

Saat, S. (2015). Faktor-faktor determinan dalam pendidikan: studi tentang makna dan kedudukannya dalam pendidikan. Jurnal Al-Ta'dib, 8(2).

Sadiman, A. S., Rahardjo, R., Haryono, A., \& Harjito. (2008). Media pendidikan pengertian, pengembangan dan pemanfaatannya. Jakarta: PT Raja Grafindo Persada.

Serlinda, Sasongko, R. N., \& Zakaria. (2019). Komitmen guru dalam meningkatkan kompetensi profesional sebagai pendidik. Jurnal Manajer Pendidikan (Mapen), 13(1), 64-68. Retrieved from https://ejournal.unib.ac.id/index.php/manajerpendidikan/article/view/7284/36 46. 
Suharto, T. (2011). Filsafat pendidikan Islam. Yogyakarta: Ar-Ruz Media.

Suriyati. (2019). Guru sebagai jabatan karir dan profesional. AL-QALAM Jurnal Kajian Islam \& Pendidikan, 11(2), 52-62.

Tafsir, A. (2002). Ilmu pendidikan dalam perspektif Islam. Bandung: PT Remaja Rosdakarya.

Undang-Undang No. 14 Tahun 2005 tentang Guru dan Dosen. (n.d.).

Undang-Undang RI No. 20 Tahun 2003 tentang Sistem Pendidikan Nasional. (n.d.).

Usman, M. U. (2002). Menjadi Guru Profesional. Bandung: PT Remaja Rosdakarya.

Zakiah, D. (2006). Ilmu Pendidikan Islam. Jakarta: Bumi Aksara.

Zuhairini. (1992). Filsafat Pendidikan Islam. Jakarta: Bumi Aksara. 